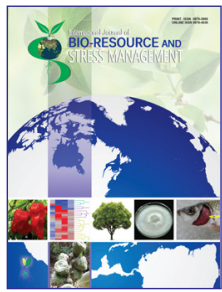

\title{
Callus Induction from the Leaves and Organogenesis from the Leaf induced Calli of Piper longum L.
}

\author{
Anupa Wasti and Krishna Kumar Pant*
}

Central Department of Botany Tribhuvan University, Kirtipur, Kathmandu, Nepal

G

Corresponding Author

Krishna Kumar Pant

e-mail: krishna.k.pant@gmail.com

Citation: Wasti and Pant, 2019. Callus Induction from the Leaves and Organogenesis from the Leaf induced Calli of Piper longum L. International Journal of Bio-resource and Stress Management 2019, 10(3):287-291. HTTPS://DOI.ORG/10.23910/ IJBSM/2019.10.3.1996

Copyright: (c) 2019 Wasti and Pant. This is an open access article that permits unrestricted use, distribution and reproduction in any medium after the author(s) and source are credited.

Data Availability Statement: Legal restrictions are imposed on the public sharing of raw data. However, authors have full right to transfer or share the data in raw form upon request subject to either meeting the conditions of the original consents and the original research study. Further, access of data needs to meet whether the user complies with the ethical and legal obligations as data controllers to allow for secondary use of the data outside of the original study.

Conflict of interests: The authors have declared no conflict of interests exist.

Acknowledgement: We are thankful to the Central Department of Botany, Tribhuvan University for providing the laboratory facilities.

\begin{abstract}
The aim of this research was the production and organogenesis of callus from leaf explants of Piper longum L. an important medicinal plant. The mother stocks were collected from the natural habitats at Ratnanagar, Chitwan and were cultivated at the central department of botany for experimental use. The basal medium used for all the experiments was Murashige and Skoog's medium and the standard sterilization, inoculation and incubation procedures were applied. The young leaves were cultured in vitro on different concentration of 2,4-D (0.5-5.0 $\mathrm{mg} \mathrm{l}^{-1}$ ) for callus induction. Among them, 3.0-4.0 $\mathrm{mg} \mathrm{l}^{-1} 2,4-\mathrm{D}$ gave hard and compact yellow colored callus. These 2,4-D mediated calli were transferred to thirty different media (BAP, NAA, Kinetin, coconut water) for organogenesis. Most of the media did not show any response but some of them responded well. For shoot bud induction from callus, $0.5 \mathrm{mg} \mathrm{l}^{-1} \mathrm{Kn}$ and $0.1 \mathrm{mg} \mathrm{l}^{-1}$ BAP responded but $0.1 \mathrm{mg} \mathrm{l}^{-1}$ BAP was found to be the best with $5 \pm 0.73$ shoot buds per culture (highly significant). Root induction on $0.1 \mathrm{mg} \mathrm{l}^{-1} \mathrm{Kn}, 1.0 \mathrm{mg} \mathrm{l}^{-1} \mathrm{BAP}+0.1 \mathrm{mg} \mathrm{l}^{-1} \mathrm{NAA}$ and $2.0 \mathrm{mg} \mathrm{l}^{-1} \mathrm{BAP}+0.1 \mathrm{mg} \mathrm{l}^{-1} \mathrm{NAA}$ were highly significant among all the media tested. Maximum number of roots ( $12 \pm 1.21$ roots per culture) was recorded from the MS medium containing $1.0 \mathrm{mg} \mathrm{l}^{-1} \mathrm{BAP}+0.1 \mathrm{mg} \mathrm{l}^{-1} \mathrm{NAA}$.
\end{abstract}

Keywords: Piper longum L., callus, shoot-buds, roots, phyto-hormones and organogenesis

\section{Introduction}

Piper longum L. belonging to the family Piperaceae is native to the IndoMalayan region. It is wild in tropical rainforest of India, Nepal, Indonesia, Malaysia, Srilanka, Timor and Phillippines (Chauhan et al., 2011). In Nepal, it is distributed in various shady places at elevations up to 800 meters. (Manandhar and Manandhar, 2002). Piper longum L. is a climbing shrub up to 3 meters long. Young shoots are downy, leaves $5-9 \mathrm{~cm}$ long and 5 $\mathrm{cm}$ wide, ovate, cordate with broad rounded lobes at base, sub-acute, entire and glabrous. Flowers are unisexual. They are in solitary, erect spikes. Female spikes $(1.25-2 \mathrm{~cm})$ are smaller than male spikes (2.5-7.5 $\mathrm{cm}$ ). Fruits ( 2.5 to $3.5 \mathrm{~cm}$ long and $5 \mathrm{~mm}$ thick) grow in fleshy spikes which are oblong, blunt and of blackish green color. (Kumar et al., 2011).

Major constituent in $P$. longum L. is piperine. Alkaloids and amides, lignans, esters, volatile oils and organic acids are also found in them. Immature spikes, roots and seeds are being used traditionally as spice and medicine in Nepal. P. longum L. is a powerful stimulant for both

\section{Article History}

RECEIVED in $14^{\text {th }}$ May 2019 RECEIVED in revised form $26^{\text {th }}$ June 2019 ACCEPTED in final form $30^{\text {th }}$ June 2019 
respiratory and digestive systems. It plays an important role in the release of metabolic heat energy. It increases the bioavailability and enhances absorption of other ingredients (Meena et al., 2009). Some medicinal and pharmacological activities are anti-oxidant activity (Natarajan et al., 2006), hepatoprotective activity (Christina et al., 2006), antiinflammatory activity (Kumar et al., 2011), anticancer activity (Pradeep and Kuttan, 2002) and antimicrobial activity (Ali et al., 2007, Singh and Rai, 2013).

The demand and dependency on traditional medicine in the developing countries is very high (Chatterjee and Ghosh, 2015). Due to all these reasons the plant attracts locals to over collect, rapid loss in its natural habitat due to the production of unviable viable seeds (Kanimazi and Sujata, 2015) and various other reasons like habitat loss have made this species vulnerable and hence the Department of Plant Resources, Nepal has included this species under their list of prioritized plants for multiplication and conservation. Although various researchers like Parida and Dhal, 2011, Padhan, 2015, Tiwari, 2016 focused on the multiplication of this species through nodal explants whereas researchers like Deka and Kalita, 2007 and Manorama and Sindhu, 2013, used axillary buds and meristems respectively for multiple shoot production. Mass propagation in short time can be made possible through intermediate callus either by direct organogenesis or by the development of somatic embryogenesis. Callus culture may also be one of the best alternatives to produce secondary metabolites in shorter time and reduce the pressure in nature. Very little work have been published so far focusing on the callus induction through leaves and their organogenesis. Hence, we focused on the callus production leading to organogenesis in the present research. Similar works have been done by various workers like (Bhat et al., 1992) through nodes; (Malathi et al., 2016) and (Sathelly et al., 2016) through leaves. The purpose of this research is to determine the combination of plant growth hormone like 2,4-D, NAA, BAP and Kinetin to leaf explants of Piper longum L. for induction of callus and its organogenesis leading to its in vitro conservation.

\section{Materials and Methods}

\subsection{Plant materials}

Plants were collected from Ratnanagar of Chitwan district (200m above sea level), Nepal and they were cultivated in pots at the Central Department of Botany, Tribhuvan University, Kirtipur, Kathmandu, Nepal for further use as required (Figure 1 ). The experiments were conducted for one year (August 2017- August 2018). Upper three to four leaves from the tips were taken in the beaker and washed under running water for half an hour with 2 drops of Tween-20. Then, they were washed with distilled water. After that, those leaves were surface sterilized by $0.1 \% \mathrm{HgCl}_{2}$ for $3-4$ minutes and washed several times with sterile water. Then the leaves were cut into size of $0.5 \mathrm{~cm}^{2}$ and inoculated in different media in culture tubes. All the transfers were done inside laminar air flow cabinet near burning Bunsen burner and culture tube mouths were sealed tightly with the help of aluminum foil and rubber bands. Then, were transferred to the culture room where artificial lights with light/dark cycle of $16 / 8$ hours were supplied continuously with $25 \pm 2{ }^{\circ} \mathrm{C}$ temperature.

\subsection{Culture media}

The solid Murashige and Skoog, 1962 (MS) medium was used as control. Strengths viz. half strength and quarter strength with hormone were used for shooting and rooting of explants, different concentration of 2,4-D $(0.5,1.0,1.5,2.0,2.5,3.0,3.5$. 4.0, 4.5 and $5.0 \mathrm{mg} \mathrm{l}^{-1}$ ) were used for callus induction from leaf explants. Similarly, different concentration of MS+Cytokinins (BAP 0.1, 0.5, 1.0, 1.5 and $2.0 \mathrm{mg} \mathrm{l}^{-1}$ and $\mathrm{Kn} \mathrm{0.1,0.5,} \mathrm{1.0,} 1.5$ and $2.0 \mathrm{mg} \mathrm{l}^{-1}$ ) were prepared and used for root and shoot proliferation responses. Similarly, the combinations of NAA (auxin) and BAP or Kinetin (cytokinin) in MS media (NAA 0.1+ BAP 0.1, NAA 0.1+BAP 0.5, NAA 0.1+BAP1.0, NAA 0.1+BAP 1.5, NAA 0.1+BAP 2.0, NAA 0.5+BAP 0.5, NAA 0.5+1.0 and NAA $0.5+B A P 1.5 \mathrm{mg} \mathrm{l}^{-1}$ ) were used for shoot and root induction from the callus. Likewise, MS+NAA $0.1 \mathrm{mg} \mathrm{l}^{-1}+10 \%$ coconut water, MS+NAA $0.5 \mathrm{mg} \mathrm{l}^{-1}+10 \%$ coconut water; $1 / 2 \mathrm{MS}+\mathrm{NAA}$ $0.1 \mathrm{mg} \mathrm{l}^{-1}+10 \%$ coconut water, $1 / 2 \mathrm{MS}+\mathrm{NAA} 0.5 \mathrm{mg} \mathrm{l}^{-1}+10 \%$ coconut water; $1 / 4 \mathrm{MS}+\mathrm{NAA} 0.1 \mathrm{mg} \mathrm{l}^{-1}+10 \%$ coconut water, $1 / 4$ MS+NAA $0.5 \mathrm{mg} \mathrm{l}^{-1}+10 \%$ coconut water were also used for callus transfer and further organogenesis responses.

\section{Results and Discussion}

This research was carried out for the callus induction from leaf explants and to find out their responses on shoot and root induction via different media combination. Leaf cultures were done on MS full strength media supplemented with different concentration of 2,4-D (0.5-5.0 $\left.\mathrm{mg} \mathrm{l}^{-1}\right)$ for callus induction. Among those ten different concentrations of 2,4-D, callus initiation was found only in four different concentrations viz. 2.5, 3.0, 3.5 and $4.0 \mathrm{mg} \mathrm{l}^{-1}$ of 2,4-D. Other concentration of 2,4-D $\left(0.5,1.0,1.5,2.0,4.5\right.$ and $\left.5.0 \mathrm{mg} \mathrm{l}^{-1}\right)$ did not show any response and hence has been omitted from the result (Table 1). All the cultures were observed for a maximum of

\begin{tabular}{|c|c|c|c|c|}
\hline \multirow{2}{*}{$\begin{array}{l}\text { Sl. } \\
\text { No. }\end{array}$} & \multirow{2}{*}{$\begin{array}{l}2,4-\mathrm{D} \text { hor- } \\
\text { mone conc. } \\
\left(\mathrm{mg} \mathrm{l}^{-1}\right)\end{array}$} & \multicolumn{2}{|c|}{ Callus morphology } & \multirow{2}{*}{$\begin{array}{c}\text { Amount of } \\
\text { callus }\end{array}$} \\
\hline & & Color & Texture & \\
\hline 1. & 2.5 & Cream & Soft & + \\
\hline 2. & 3.0 & Yellow & Harder & ++ \\
\hline 3. & 3.5 & Light yellow & Hard & ++ \\
\hline 4. & 4.0 & Light yellow & Hard & ++ \\
\hline
\end{tabular}

'+'Average amount of callus (upto $0.5 \mathrm{~cm}^{2}$ ) and '++' Large amount of callus $\left(>0.5 \mathrm{~cm}^{2}\right)$. 
12 weeks in which the leaf explants either became brown or remained yellow.

The earliest sign of callus induction was observed within 1.5 weeks of leaf culture on MS+2.5 $\mathrm{mg} \mathrm{l}^{-1}$ 2,4-D. Thus induced calli were of cream colored and soft in texture. The time requirement for callus induction, callus color and texture however varied greatly among the different concentrations of 2,4-D. $3.0 \mathrm{mg} \mathrm{l}^{-1}$ 2,4-D induced large amount of yellow colored harder callus after 6.33 weeks of leaf culture. Similarly, $3.5 \mathrm{mg}$ $\mathrm{I}^{-1}$ of 2,4-D as well as $4.0 \mathrm{mg} \mathrm{I}^{-1}$ of 2,4-D also produced hard light yellow colored callus within 5.83 and 7 weeks of leaf culture respectively. From the Table 1., it can be concluded that the optimum concentration of 2,4-D required for callus induction from the leaves of $P$. longum $\mathrm{L}$. is between 2.5-4.0 $\mathrm{mg}^{\mathrm{l}^{-1}}$ (Figure $\mathrm{a}, \mathrm{b}$ and $\mathrm{c}$ ). However, Manorama and Sindhu, (2013) reported that MS medium supplemented with $0.5 \mathrm{mg}$ $\mathrm{I}^{-1} 2,4-\mathrm{D}$ as the best for callus production with $100 \%$ success in leaf explants of $P$. longum $L$. It can also be concluded from the results that yellowish and hard calli are more proliferative than the creamy soft ones.

The calli produced from 2,4-D was transferred (sub-cultured) to different combination of media for proliferation and regeneration (Table 2). Among all the 30 treatments, only two

Table 2: 2,4-D mediated callus color and their differentiation into shoot buds and roots per culture on different hormone combinations after third subculture

\begin{tabular}{|c|c|c|c|c|}
\hline $\begin{array}{l}\text { SI. } \\
\text { No. }\end{array}$ & $\begin{array}{l}\text { Media combi- } \\
\text { nation }\end{array}$ & $\begin{array}{l}\text { Callus } \\
\text { color }\end{array}$ & $\begin{array}{l}\text { Roots/ } \\
\text { culture }\end{array}$ & $\begin{array}{l}\text { Shoot buds/ } \\
\text { culture }\end{array}$ \\
\hline 1. & MS & $\begin{array}{l}\text { Yellowish } \\
\text { green }\end{array}$ & $1.33 \pm 0.33$ & - \\
\hline 2. & $\mathrm{MS}+0.1 \mathrm{BAP}$ & Green & - & $5 \pm 0.73$ \\
\hline 3. & $\begin{array}{l}\mathrm{MS}+1.0 \\
\mathrm{BAP}+0.1 \mathrm{NAA}\end{array}$ & Green & $12 \pm 1.21$ & - \\
\hline 4. & $\begin{array}{l}\mathrm{MS}+2.0 \\
\mathrm{BAP}+0.1 \mathrm{NAA}\end{array}$ & Green & $9.67 \pm 1.56$ & - \\
\hline 5. & $\mathrm{MS}+0.1 \mathrm{Kn}$ & Green & $6.83 \pm 0.87$ & - \\
\hline 6. & $\mathrm{MS}+0.5 \mathrm{Kn}$ & $\begin{array}{l}\text { Yellowish } \\
\text { green }\end{array}$ & - & $3.17 \pm 0.54$ \\
\hline 7. & $\begin{array}{l}\mathrm{MS}+1.5 \\
\mathrm{Kn}+0.5 \mathrm{NAA}\end{array}$ & Light green & $3.33 \pm 0.33$ & - \\
\hline 8. & $\begin{array}{l}\mathrm{MS}+2.0 \\
\mathrm{Kn}+0.5 \mathrm{NAA}\end{array}$ & Light green & $2.17 \pm 0.47$ & - \\
\hline 9. & $\begin{array}{l}\mathrm{MS}+10 \% \\
\mathrm{CW}+0.5 \mathrm{NAA}\end{array}$ & $\begin{array}{l}\text { Greenish } \\
\text { brown }\end{array}$ & $2 \pm 0.5$ & - \\
\hline 10. & $\begin{array}{l}\mathrm{MS} 1 / 2+10 \% \\
\mathrm{CW}+0.1 \mathrm{NAA}\end{array}$ & $\begin{array}{l}\text { Greenish } \\
\text { brown }\end{array}$ & $2 \pm 0.36$ & - \\
\hline 11. & $\begin{array}{l}\mathrm{MS} 1 / 4+10 \% \\
\mathrm{CW}+0.5 \mathrm{NAA}\end{array}$ & $\begin{array}{l}\text { Greenish } \\
\text { brown }\end{array}$ & $3.33 \pm 1.02$ & - \\
\hline
\end{tabular}

The treatments described in the methodology but showed no response at all have been omitted. viz. MS+BAP $0.1 \mathrm{mg} \mathrm{l}^{-1}$ and MS+Kinetin $0.5 \mathrm{mg} \mathrm{l}^{-1}$ were able to induce shoot buds and the highest number of buds recorded were $5 \pm 0.73$ on $0.1 \mathrm{mg} \mathrm{l}^{-1} \mathrm{BAP}$ (Figure $\mathrm{d}$ and e). This indicates that shoot proliferation from the callus is much more difficult than roots. The result was on agreement with Sathelly et al. (2016) though shoot buds were very small until three months of culture. Basak et al. (2014) also found difficulty in shoot regeneration of $P$. longum $\mathrm{L}$. similar to our results. Bhatt and Dhar (2004) also reported in Myrica esculenta that cytokinin promoted shoot bud's multiplication but prevented shoot elongation. Bhat et al. (1995) reported that low BAP induced high shoot buds from callus and higher concentration of BAP suppressed shoot regeneration and turned callus into green and nodular similar to our findings. Similar results were reported by Rubluo and Barroso (1992) as well as by Anand and Rao (2000). This result shows that the cytokinin in general at a lower concentration is effective in shoot bud induction from the callus and at the same time BAP is more effective than Kinetin. Malathi et al. (2016) reported that BAP showed better response than Kinetin in callus proliferation and regeneration, similar to the present investigation. The color and texture of the callus also show some relationship in both in callus growth and organogenesis. Generally, harder friable calli with pale yellow to green color were observed to be performing better than the softer creamy to brownish ones in all respects.

The 2,4-D initiated calli failed to root in almost all the concentrations of both the cytokinins (BAP and $\mathrm{Kn}$ ) alone except $\mathrm{Kn} 0.1 \mathrm{mg} \mathrm{l}^{-1}$. This indicates that cytokinins alone generally do not induce roots from the callus similar to Azad et al., (2003), who suggested that BAP only do not produce roots because in vitro root initiation, development and elongation requires auxin. The root induction on $0.1 \mathrm{mg} \mathrm{l}{ }^{11}$ and basal MS (control) might be because of the residual effect of the previous media (i.e. 2,4-D). Among the auxin-cytokinin combinations, a higher cytokinin concentration $\left(\geq 1 \mathrm{mg} \mathrm{l}^{-1}\right)$ with lower auxin (0.1-0.5 mg l-1) concentration seems to be optimum for inducing roots from the callus (Table 1., Figure $f, g$, $h$ and i).

Highest number of roots was recorded on MS supplemented with $1.0 \mathrm{mg} \mathrm{l}^{-1}$ BAP and $0.1 \mathrm{mg} \mathrm{l}^{-1}$ NAA (Figure f). Basak et al. (2014) stated that if suitable growth conditions are available, roots can be initiated but there is difficulty in shoot regeneration of $P$. longum $\mathrm{L}$. In the present investigation also, there was initiation of roots in many other media like MS supplemented with Kinetin, BAP, NAA, MS, $1 / 2 \mathrm{MS}$ and $1 / 4 \mathrm{MS}$ supplemented with $10 \%$ coconut water and NAA. In almost every case, the requirement of auxin (NAA) was evident for root induction and hence, it can be concluded that auxin is necessary for root induction from the calli of this species. Hartmann et al. (1996) stated that most of the leaf explants are likely to initiate more roots than shoot buds because of the reason that leaves culture do not include an axillary bud. 

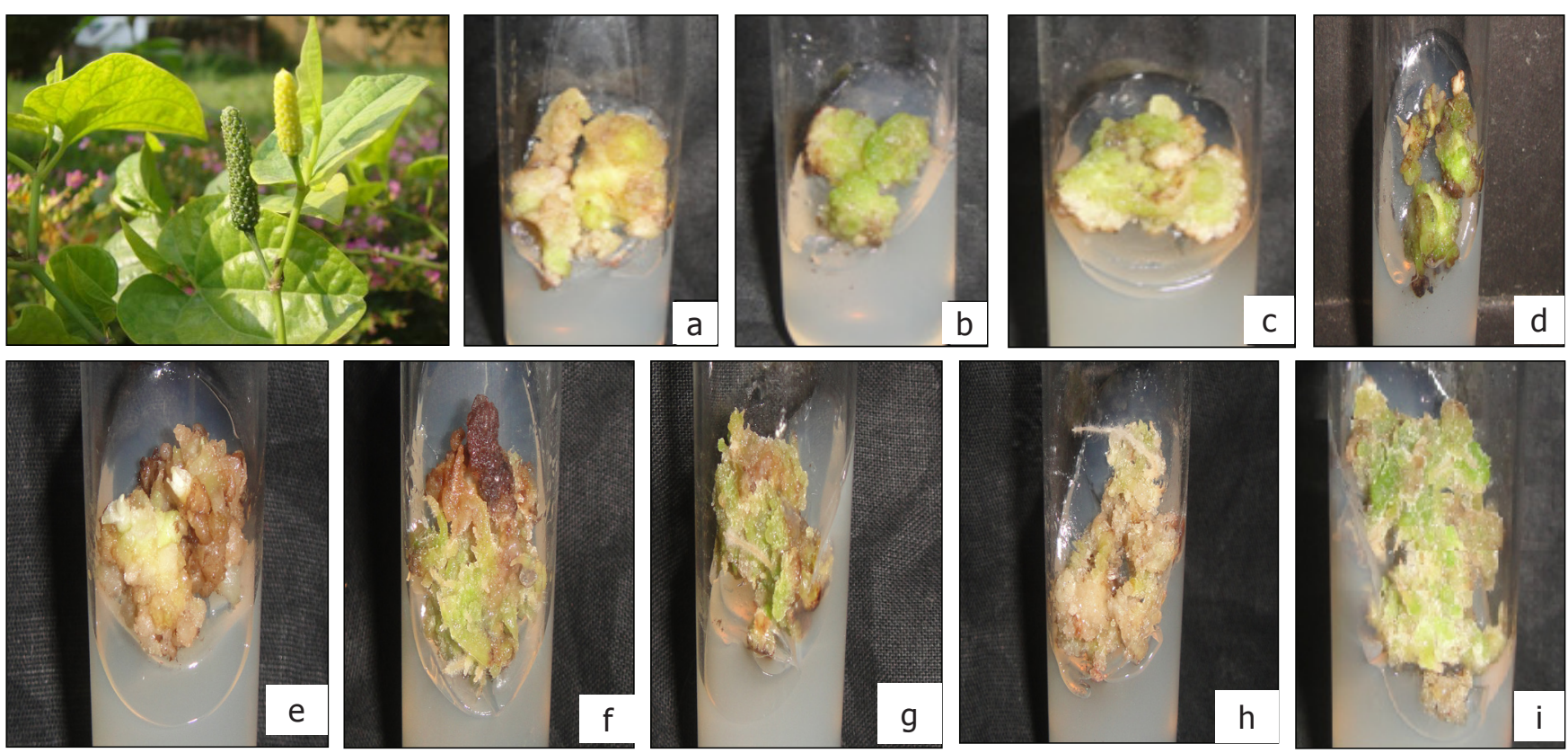

Figure 1: Habit (mother plant); Figure. a-i: Organogenesis of 2,4-D mediated callus on different media (a) Hard callus on 3.0 $\mathrm{mg} \mathrm{l}^{-1}$ 2,4-D after 7 weeks of leaf culture (b) Hard callus on $3.5 \mathrm{mg} \mathrm{l}^{-1}$ 2,4-D after 6 weeks of leaf culture (c) Hard callus on 4.0 mg l-1 2,4-D after 7 weeks of leaf culture (d) Shoot bud induction on MS+0.1 mg l-1 BAP within 12 weeks of callus transfer (e) Shoot bud induction on $\mathrm{MS}+0.5 \mathrm{mg} \mathrm{l}^{-1} \mathrm{Kn}$ within 12 weeks of callus transfer (f) Root induction on MS+1.0 mg $\mathrm{l}^{-1} \mathrm{BAP}+0.1 \mathrm{mg}$ $\mathrm{I}^{-1}$ NAA within 12 weeks of callus transfer $(\mathrm{g})$ Root induction on MS+2.0 mg l-1 BAP+0.1 mg l-1 NAA within 12 weeks of callus transfer (h) Root induction on MS+1.5 mg l-1 $\mathrm{Kn}+0.5 \mathrm{mg} \mathrm{l}^{-1} \mathrm{NAA}$ within 12 weeks of callus transfer (i) Root induction on MS+2.0 $\mathrm{mg} \mathrm{l}^{-1} \mathrm{Kn}+0.5 \mathrm{mg} \mathrm{l}^{-1} \mathrm{NAA}$ within 12 weeks of callus transfer

\section{Conclusion}

Based on the current investigation, MS+3.0 $\mathrm{mg} \mathrm{l}^{-1}$ of 2,4-D was the best for callus induction from leaves of Piper longum $\mathrm{L}$. and those leaf induced calli showed better results in shoot bud induction on MS containing $0.1 \mathrm{mg} \mathrm{l}^{-1}$ of BAP whereas the best media for root induction from calli was MS with $2.0 \mathrm{mg}$ $\mathrm{I}^{-1} \mathrm{BAP}+0.1 \mathrm{mg} \mathrm{l}^{-1} \mathrm{NAA}$. Hard friable calli with yellow to green color showed better proliferation as well as organogenesis.

\section{Acknowledgement}

We are thankful to the Central Department of Botany, Tribhuvan University for providing the laboratory facilities.

\section{References}

Ali, A.M., Alam, N.M., Yeasmin, M.S., Khan, A.M., Sayeed, M.A., 2007. Antimicrobial screening of different extracts of Piper longum L. Research Journal of Agriculture and Biological Sciences 3(6), 852-857.

Anand, A., Rao, C.S., 2000. A rapid in vitro propagation protocol for Piper barberi Gamble, a critically endangered plant. In vitro Cellular and Developmental Biology- Plant 36, 61-64.

Azad, M.A.K., Amin, M.N., Begum, F., 2003. Rapid clonal propagation of a medicinal plant Adhatoda vasica Nees. using tissue culture techniques. Online Journal of Biological Science 3, 172-182.

Basak, U.C., Dash, D., Jena, G.J.P., Mahapatra, A.K., 2014. New technique for adventitious rooting and clonal propagation of Piper longum L. (pippali) through leaf cuttings. African Journal of Plant Science 8(2), 108-112.

Bhat, S.R., Chandal, K.P.S., Malik, S.K., 1995. Plant regeneration from various explants of cultivated Piper species. Plant Cell Reports 14, 398-402.

Bhat, S.R., Kackar, A., Chandal, K.P.S., 1992. Plant regeneration from callus culture of Piper longum L. by organogenesis. Plant Cell Reports 11, 525-528.

Bhatt, I., Dhar, U., 2004. Factors controlling micropropagation of Myrica esculenta buch.-Ham. Ex D. Don: A high value wild edible plant of Kumaun Himalaya. African Journal of Biotechnology 3, 534-540.

Chatterjee, T., Ghosh, B., 2015. Simple Protocol for Micropropagation and in Vitro Conservation of Plumbago zeylanica L: An Important Indigenous Medicinal Plant. International Journal of Bio-resource and Stress Management 6(1), 068-075.

Chauhan, S.R., Patel, A., Macwan, C., Parel, M., 2011. Phytochemical and therapeutical potential of Piper longum Lin. A review. International Journal of Research in Ayurveda and Pharmacy 2(1), 157-161.

Christina, A.J.M., Saraswathy, G.R., Robert, S.H., Kothai, R., Chidambaranathan, N., Nalini, G., Therasal, R.L., 2006. 
Inhibition of $\mathrm{CCl} 4$-induced liver fibrosis by Piper longum Linn. Phytomedicine 13(3), 196-198.

Deka, A.C., Kalita, M.C., 2007. In vitro regeneration of Piper longum from axillary buds, a biopharmaceutically potent medicinal plant. The Bioscan 2(4), 7-11.

Hartmann, H.T., Kester, D.E., Davies, F.T., Geneve, R.L., 1996. Plant Propagation, Principles and Practices. $6^{\text {th }}$ ed. Prentice Hall: Upper Saddle River, New Jersey.

Kanimazi, K., Sujata, V.S., 2015. Reproductive biology of Piper longum L. Journal of Tropical agriculture 53(2), 206-212.

Kumar, S., Kamboj, J., Sharma, S., 2011. Overview for various aspects of the health benefits of Piper longum Linn. fruit. Journal of acupuncture and meridian studies 4(2), 134-140.

Malathi, S., Singh, V.P., Saraswati, S.S., Sakhubi, H.T., Preeti, P.M., 2016. Influence of different media on shoot regulation, shoot multiplication and callus induction in long pepper (Piper longum Lin.) The Asian Journal of Horticulture 11(1), 52-57.

Manandhar, N.P., Manandhar, S., 2002. Plants and People of Nepal. Timber Press, 599.

Manorama, S., Sindhu, S., 2013. In vitro micropropagation of Piper longum L. through meristem culture. International Journal of Universal Pharmacy and Bioscience 2(2), 156-160.

Meena, A.K., Bansal, P., Kumar, S., 2009. Plants - herbal wealth as a potential source of ayurvedic drugs. Asian Journal of Traditional Medicines 4(4), 152-170.

Murashige, T., Skoog, F., 1962. A revised medium for rapid growth and bio assay with tobacco tissue culture. Physiologia Plantarum 15, 473-497.

Natarajan, K.S., Narasimhan, M., Shanmugasundaram, K.R., Shanmugasundaram, E.R., 2006. Antioxidant activity of a salt/spice/herbal mixture against free radical induction. Journal of Ethnopharmacology 105(1-2), 76-83.

Padhan, B., 2015. Regeneration of plantlets of Piper longum L. through in vitro culture from nodal segments. Journal of Applied Biology and Biotechnology 3(5), 35-39.

Parida, R., Dhal, Y., 2011. A study on the micropropagation and antioxidant activity of Piper longum (an important medicinal plant). Journal of Medicinal Plant Research 5(32), 6991-6994.

Pradeep, C.R., Kuttan, G., 2002. Effect of piperine on the inhibition of lung metastasis induced B16F-10 melanoma cells in mice. Clinical and Experimental Metastasis 19(8), 703-708.

Rubluo, A., Barroso, A.L., 1992. In Vitro morphogenetic responses and cytokinin-auxin interaction for callus production in pepper. Anales del Institoto de Biologia, Universidad Nacional Autonoma de Mexico, Bot. 63, 195-201.

Sathelly, K., Podha, S., Mangamuri, U., Kaul, T., 2016. Establishment of efficient regeneration system from leaf disc in long pepper an important medicinal plant (Piper longum Lin). Medicinal and Aromat Plants 5, 248. doi: 10.4172/2167-0421.1000248.

Singh, C., Rai, N.P., 2013. In vitro antibacterial activity of Piper longum $L$. fruit. International Journal of Pharmaceutical Sciences Review and Research 18(2), 89-91.

Tiwari, R., 2016. Standardization of efficient protocol for sterilization and media for direct shoot regeneration from nodal segments of medicinal herb Piper longum L. Journal of Plant Biochemistry and Physiology 4, 163. doi: 10.4172/2329-9029.1000163. 